\title{
Optimization of electro-kinetic process for remediation of soil contaminated with phenanthrene using response surface methodology
}

\author{
Sudabeh Pourfadakari ${ }^{1}$ - Sahand Jorfi ${ }^{2}$ - Aliakbar Roudbari ${ }^{3}$ - Allahbakhsh Javid ${ }^{3}$. Seyedeh Solmaz Talebi ${ }^{4}$. \\ Seid Kamal Ghadiri ${ }^{3}$ (D) Nader Yousefi ${ }^{5}$
}

Received: 19 April 2020 / Accepted: 11 August 2020 / Published online: 22 August 2020

(C) Springer-Verlag GmbH Germany, part of Springer Nature 2020

\begin{abstract}
The objective of this work was to investigate the modification of soil contaminated with phenanthrene (PHE) by electro-kinetic remediation (EKR) process using response surface methodology $(\mathrm{RSM})$. The soil sample was obtained from the subgrades $(0-30 \mathrm{~cm})$ of an area close to Shahroud City, Northeast of Iran. The effect of variables such as initial pH, voltage, electrolyte concentration, and reaction time on PHE removal was studied. Based on the results obtained from the central composite design (CCD) experiment, the highest and lowest amount of PHE removal was 97 and $20 \%$, respectively. In this study, the variables $\mathrm{A}, \mathrm{B}, \mathrm{C}, \mathrm{AB}, \mathrm{AC}$, and $\mathrm{C}^{2}$ with a $p$ value $<0.05$ were significant model terms and the parameter of the lack of fit was not significant $(p$ value $=0.0745)$. Findings indicated that the "predicted R-squared" of 0.9670 was in reasonable agreement with the "adj R-squared" of 0.9857 and the plot of residual followed a normal distribution and approximately linear. Also, the kinetic rates of the removal PHE by the EKR process best fitted with a first-order kinetic model $\left(R^{2}: 0.926\right)$. Results of the investigation of the effective variables showed that in values of $\mathrm{pH} 3$, time of $168 \mathrm{~h}$, voltage of $3 \mathrm{~V}$, and electrolyte concentration of $4 \mathrm{mg} / \mathrm{L}$, the removal efficiency of PHE reached $96.6 \%$.
\end{abstract}

Keywords Phenanthrene $\cdot$ Soil contamination $\cdot$ Electro-kinetic remediation $\cdot$ RSM

\section{Introduction}

During activity industries, petrochemical, and petroleum, large amounts of organic and inorganic pollutants are released into the environment (Jahangiri et al. 2019; Mohan et al. 2006). One important class of these compounds is polyaromatic hydrocarbons (PAHs). They are hydrophobic organic compounds (HOCs) that constitute two or more

Responsible Editor: Weiming Zhang

Seid Kamal Ghadiri kamalgh2005@gmail.com

Nader Yousefi

yousefinader@gmail.com

Sudabeh Pourfadakari porfadakar@gmail.com

Sahand Jorfi

sahand369@yahoo.com

Aliakbar Roudbari

roodbari@shmu.ac.ir

Allahbakhsh Javid

cavid_a@yahoo.com

Seyedeh Solmaz Talebi

taleb.solmaz@yahoo.com
1 Systems Environmental Health and Energy Research Center, The Persian Gulf Biomedical Sciences Research Institute, Bushehr University of Medical Sciences, Bushehr, Iran

2 Department of Environmental Health Engineering, School of Public Health, Ahvaz Jundishapur University of Medical Sciences, Ahvaz, Iran

3 Department of Environmental Health Engineering, School of Public Health, Shahroud University of Medical Sciences, Shahroud, Iran

4 Department of Epidemiology, School of Public Health,Shahroud University of Medical Sciences, Shahroud, Iran

5 Department of Environmental Health Engineering, School of Public Health, Tehran University of Medical Sciences, Tehran, Iran 
benzene rings (Kumar et al. 2018). PAHs contain 16 components, which most of them have specifications such as being carcinogenic, mutagenic, and teratogenic (Makkar and Rockne 2003). These substances with special characteristics, such as low volatility and low solubility in water, are easily adsorbed in soil particles and sediments and caused soil contamination. Hence, their removal from the environment is essential (Alcántara et al. 2009). Phenanthrene (PHE) is a polycyclic aromatic hydrocarbon composition with a chemical formula of $\mathrm{C}_{14} \mathrm{H}_{10}$ consisting of three benzene rings, which, due to low biodegradability and high persistence in the environment, is important for human health (Ebrahimi et al. 2013; Shankar et al. 2019). There are different methods such as phytoremediation, bioremediation, and chemical remediation for the removal of PAHs from soil (Amin et al. 2016; Pourfadakari et al. 2019; Zdeněk and Pavel 2018). In a study conducted by Baneshi et al. (2014) for the removal of phenanthrene and pyrene with the concentration of $100-300 \mathrm{mg} / \mathrm{kg}$ from the soil, using two plants Sorghum and Onobrychis sativa, the results obtained showed that after 120 days, the removal efficiency of PYR and PHE in soil significantly increased, that is, $74.1-73.84 \%$ of PYR and $85.02-85.2 \%$ of PHE were removed (Baneshi et al. 2014). The results of the study performed by Qiu et al. (2019) in the remediation of contaminated soil to PAH by surfactant (SDS) and ironactivated persulfate oxidation process showed that at SDS concentration of $20 \mathrm{~g} / \mathrm{L}$, the removal efficiencies of phenanthrene, fluoranthene, and pyrene reached $37 \%, 40 \%$, and $44 \%$, respectively. At the dosage of $2 \mathrm{~g} / \mathrm{L}$ of $\mathrm{SiO}_{2} / \mathrm{nZVI}$, PS solution $(50 \mathrm{mM})$, and time of $30 \mathrm{~min}$, the removal efficiencies of PHE, FLU, and PYR were $75 \%, 85 \%$, and $87 \%$, respectively (Qiu et al. 2019). In the other study done by Shin and Kim (2004), the removal of phenanthrene and diesel from sand with concentrations of $200 \mathrm{mg} / \mathrm{kg}$ and $20,000 \mathrm{mg} / \mathrm{kg}$, by the surfactant (Tween 80) and rhamnolipid biosurfactant with the value $\mathrm{CMC}$ of $50 \mathrm{mg} / \mathrm{L}$, was investigated. The results obtained showed the percentage recovery by rhamnolipid was higher than with the Tween 80 , and the amount of removal for 20 pore volumes was 67 and 37\%, respectively. In optimum conditions, the rhamnolipid removed as much as $70 \%$ of the phenanthrene and $60 \%$ of the diesel in the sand (Shin and Kim 2004). These methods have many limitations such as high cost, long time, failure to completely remove pollutants, and production of byproducts (Huang et al. 2012). Recently, electro-kinetic remediation (EKR) as new technology has been used for the removal of the organic and inorganic contaminants from soil (Lin et al. 2016). The main advantages of the EKR process include flexibility, non-toxicity of the reagents, simplicity, needs less space, cost-effective, and high efficiency in the removal of pollutants. Also, it can be performed as an in situ and ex situ method (Jorfi et al. 2017b; Moghadam et al. 2016). The transport mechanisms of pollutants in soil in the EKR process are a combination of several mechanisms (electrolysis, electro-osmosis, and electro- migration). In the EK process (electrolysis), the oxygen and hydrogen ions $\left(\mathrm{H}^{+}\right)$are produced in the anode electrode surface, while hydroxide ions $\left(\mathrm{OH}^{-}\right)$and hydrogen gas are generated in the cathode electrode surface (Eqs. 1 and 2). Therefore, migration of these ions into the soil close to the anode and cathode could cause acidic and basic states in the soil, respectively. The protons generated at anode could move two times greater than the electron $\mathrm{OH}^{-}$ions. Therefore, the acidic condition dominates the system until hydrogen ion and hydroxyl ion combine near the cathode and generate water. It means that near the cathode is a basic zone and close to the anode is an acidic zone. The size of these zones depends on the soil properties and ion movements. During the electro-migration or electro-osmotic advection, $\mathrm{H}^{+}$and $\mathrm{OH}^{-}$ions and other ions migrate towards the oppositely charged electrode, which causes desorption or pollutant separation from soil (Saichek and Reddy 2003).

At the anode:

$2 \mathrm{H}_{2} \mathrm{O} \rightarrow \mathrm{O}_{2}+4 \mathrm{H}^{+}+4 e^{-}$

At the cathode:

$4 \mathrm{H}_{2} \mathrm{O}+4 e^{-} \rightarrow 2 \mathrm{H}_{2}+4 \mathrm{OH}^{-}$

In the EKR process, one of the chemicals generated at the surface of the electrode is hydrogen peroxide $\left(\mathrm{H}_{2} \mathrm{O}_{2}\right)$, which when iron ions exist in soil, it would cause production of hydroxyl radical. For this purpose and generation of divalent iron ions $\left(\mathrm{Fe}^{2+}\right)$, the iron sheet, due to having advantages such as abundance, simplicity, and low cost, was used as an anode electrode. In other words, $\mathrm{Fe}^{2+}$ ions are generated via the oxidation of iron in the anode electrode surface (Eq. (3)). In addition, in this study, the graphite electrodes due to their low cost, large specific surface area, chemical stability, and high mechanical strengths, were used as a cathode electrode for generated hydrogen peroxide (Eqs. (5, 6 and 7)) (Jorfi et al. 2017b; Takdastan et al. 2018). Then, according to Eq. (4), $\mathrm{H}_{2} \mathrm{O}_{2}$ reacts with $\mathrm{Fe}^{2+}$ ions to produce hydroxyl radical $\left(\mathrm{OH}^{\circ}\right)$ as an oxidant agent with the ability to decompose organic compounds (Díez et al. 2016; Plakas et al. 2016).

At the anode:

$\mathrm{Fe} \rightarrow \mathrm{Fe}^{2+}+2 e^{-}$ 
$\mathrm{Fe}^{2+}+\mathrm{H}_{2} \mathrm{O}_{2} \rightarrow \mathrm{Fe}^{3+}+\mathrm{OH}^{-}+\mathrm{OH}^{\cdot}$

At the cathode:

$\mathrm{O}_{2}+2 \mathrm{H}^{+}+2 e^{-} \rightarrow \mathrm{H}_{2} \mathrm{O}_{2}$

$e^{-}+\mathrm{Fe}^{3+} \rightarrow \mathrm{Fe}^{2+}$

$\mathrm{RH}($ Pollutant $)+\mathrm{OH}^{*} \rightarrow \mathrm{R}^{\bullet}+\mathrm{H}_{2} \mathrm{O}$

Response surface methodology (RSM) is combined with mathematical and statistical methods, which are used for designing experiments and analyzing the effects of various variables in the removal of pollutants. Also, the RSM is applied to optimize the process for finding the values of variables with positive effect in response. Valorization of biomass into aminefunctionalized bio graphene for efficient ciprofloxacin adsorption in water-modeling and optimization study. PLoS ONE. https://doi.org/10.1371/journal.pone.0231045. Accessed 14 April 2020. One of the main advantages of this method is reducing the number of experimental. The response surface methodology in the form of several classes, such as Box-Behnken design, central composite design, hybrid design, and three-level factorial design, is applicable. Among these methods, the central composite design (CCD) is the most used (Javid et al. 2020). In previous studies, methods such as soil washing using surfactants, biosurfactant, and advanced oxidation processes were taken for soil remediation. However, the main innovation of the current study is the removal of polycyclic aromatic hydrocarbons (phenanthrene) from soil, which has not been done at the oil areas close to Shahroud City by the EKR process. In this work, PHE removal from soil using the electro-kinetic remediation process as an environmentally friendly method using the response surface methodology was investigated, and the effects of operational variables such as initial $\mathrm{pH}$, voltage, electrolyte concentration, and reaction time in the removal of PHE were determined. Finally, the energy consumption was calculated and intermediates of PHE degradation were identified.

\section{Material and methods}

\section{Chemicals}

All chemicals used in the present study were of analytical grades. Phenanthrene (PHE, $\geq 99.5 \%$ ), acetone $\left(\mathrm{CH}_{3} \mathrm{COCH}_{3}, 99.5 \%\right)$, and n-hexane $\left(\mathrm{CH}_{3}\left(\mathrm{CH}_{2}\right)_{4} \mathrm{CH}_{3}, \geq\right.$ 95.0\%) were purchased from Sigma-Aldrich, USA. Also, chemical hydrochloric acid $(\mathrm{HCl})$, sodium chloride $(\mathrm{NaCl})$, and sodium hydroxide $(\mathrm{NaOH})$ were provided from Merck Co., Germany. The graphite and iron sheets were purchased from PATF industrial Co., Iran.

\section{The soil samples}

The soil sample was obtained from the subgrades $(0-30 \mathrm{~cm})$ of an area close to Shahroud City, Northeast of Iran. First, the soil sample was sieved with the ASTM standard to obtain particles with a pore diameter of $2-4 \mathrm{~mm}$. Then, the soil was washed twice with acetone solution and dried in an oven at $60^{\circ} \mathrm{C}$ for $24 \mathrm{~h}$. To obtain a final concentration of PHE a contaminated soil ( $200 \mathrm{mg} / \mathrm{kg}$ dry soil), a certain amount of PHE was dissolved in $\mathrm{n}$-hexane solution and added to the soil. Afterwards, contaminated soil was shaken for $2 \mathrm{~h}$ at 200 rpm. Finally, for solvent evaporation, the mixed samples were kept at a room temperature for $24 \mathrm{~h}$. The moisture content of the soil was measured by the thermogravimetric method. Xray fluorescence spectroscopy (XRF, model: PW1410, Holland) analysis was used for determining the chemical substances of soil particles.

\section{Lab-scale experiments}

The experiments were carried out in a reactor of a rectangular Plexiglas with a total volume of $700 \mathrm{~mL}$ equipped with the two-graphite electrode and iron with dimensions of $(20 \mathrm{~cm}$ length, $1 \mathrm{~cm}$ thickness, and $5 \mathrm{~cm}$ width). In this study, the effect of variables such as initial $\mathrm{pH}$, voltage, electrolyte concentration, and reaction time on PHE removal was studied using a soil to water ratio of 1:2. To adjust $\mathrm{pH}$, the solution of $\mathrm{HCL}$ and $\mathrm{NaOH} 0.1 \mathrm{M}$ was used and the $\mathrm{pH}$ value of soil was tested using digital $\mathrm{pH}$ meter (CyberScan Eutech instruments 5500 model). The electric power was supplied by a laboratory DC power supply (model: PS 303D).

\section{Experimental design and modeling}

The RSM-based central composite design (CCD) was used to statistically analyze the experimental data and explore the relationship between the independent variables and response. In this research, 30 runs were determined using the RSM with 6 repeats (including $2 \times 3=6$ axial points and $2^{3}=8$ design points). The removal percentage of PHE (Y1) was selected as the response, which was the dependent variable. Besides, $\mathrm{pH}$ (A), time (B), voltage (C), and electrolyte concentration (D) were considered independent variables. The lowest and highest levels of variables are shown in Table 1.

The second-order polynomial regression model for the variables is presented according to Eq. (8) (Javid et al. 2020):

$$
\mathrm{Y}=\beta_{0}+\sum_{\mathrm{i}=1}^{\mathrm{k}} \beta_{\mathrm{i}} \mathrm{x}_{\mathrm{i}}+\sum_{\mathrm{i}=1}^{\mathrm{k}} \beta_{\mathrm{ii}} \mathrm{x}_{\mathrm{ii}}+\sum_{\mathrm{i}=1}^{\mathrm{k}-1} \sum_{\mathrm{j}=2}^{\mathrm{k}} \beta_{\mathrm{ij}} \mathrm{x}_{\mathrm{i}} \mathrm{x}_{\mathrm{j}}+\varepsilon \mathrm{i} \neq \mathrm{j}
$$

where $Y$ is the response; $x_{\mathrm{i}}$ and $x_{\mathrm{j}}$ are independent variables that affect $Y ; \beta_{0}$ is the constant; $\beta_{\mathrm{i}}$ and $\beta_{\mathrm{ii}}$ are the linear and second-order coefficients, respectively; $\beta_{\mathrm{ij}}$ is interaction 
Table 1 The levels of independent variables used in this study for experimental design

\begin{tabular}{lllll}
\hline Variable & Unit & \multicolumn{2}{l}{ Level } & \\
\cline { 3 - 5 } & & Low $(-1)$ & Center & High (+ 1) \\
\hline $\mathrm{pH}$ & - & 3 & 6 & 9 \\
Time & $\mathrm{h}$ & 24 & 96 & 168 \\
Voltage & $\mathrm{V}$ & 0.5 & 1.75 & 3 \\
Electrolyte concentration & $\%$ & 1 & 2.5 & 4 \\
\hline
\end{tabular}

effect; $k$ is the number of input variables; and $\varepsilon$ is a random error (Kalali et al. 2011).

\section{Analytical methods}

PHE was extracted from soil according to the procedure recommended in EPA method 3550c (SWE 1996). Briefly, $2 \mathrm{~g}$ of the contaminated soil sample was put in a Falcon tube containing $10 \mathrm{~mL}$ of $\mathrm{n}$-hexane/acetone with a 1:1 (v/v) ratio (Von Lau et al. 2014; Zhang 2015). Ultrasonic (Hielscher: UP $400 \mathrm{~S}$, Germany) was employed at a power of $400 \mathrm{~W}$ for $10 \mathrm{~min}$ for solution continuous mix. Then, the solution was filtered using polytetrafluoroethylene (PTFE) and a little amount of filtered solution was separated to perform the analysis. The PHE concentration in the contaminated soil sample was determined using the gas chromatography-mass spectrometry (GC-MS) analysis (model: Agilent 7890, USA) with HP5-MS capillary column $(30 \mathrm{~m} \times 0.32 \mathrm{~mm} \times 0.25-\mu \mathrm{m}$ film thickness). Helium as the carrier gas was injected to the column at $1-\mathrm{mL} / \mathrm{min}$ flow rate. The oven temperature program was as follows: $100^{\circ} \mathrm{C}$ at $10^{\circ} \mathrm{C} / \mathrm{min}$ with a lag time of $1 \mathrm{~min}$; then, temperature was raised to $150{ }^{\circ} \mathrm{C}$ at $25^{\circ} \mathrm{C} / \mathrm{min}$, then ramped to $225{ }^{\circ} \mathrm{C}$ in $2 \mathrm{~min}$. The injection port temperature was $280^{\circ} \mathrm{C} 1 / 10$. The treatment efficiency of PHE in soil was calculated in Eq. (9) (Pourfadakari et al. 2020):

$\omega^{\prime}=\left(\mathrm{C}_{0}-\mathrm{C}\right) \times 100 / \mathrm{C}_{0}$

where $\omega$ is the PHE removal efficiency, $\operatorname{Crem} C_{0}$ and $C$ are the initial and remaining PHE concentrations in the soil before and after the EKR process.

\section{Results and discussion}

\section{Soil analysis}

The soil used in this experiment was loamy silty with clay (24\%), silt (65\%), and sand (28\%). The physical and chemical characteristics of the soil are presented in Table 2. The main
Table 2 The physicochemical properties of soil used in this study

\begin{tabular}{llll}
\hline Characteristic & Value $(\%)$ & Characteristic & Value (\%) \\
\hline Soil type & Loamy silty & L.O.I & 19.1 \\
Sand & 28 & $\mathrm{Al}_{2} \mathrm{O}_{3}$ & 5.3 \\
Clay & 24 & $\mathrm{MgO}$ & 2.6 \\
Silt & 65 & $\mathrm{Fe}_{2} \mathrm{O}_{3}$ & 2.1 \\
$\mathrm{Moisture} \mathrm{content} \mathrm{( \% )}$ & 10 & $\mathrm{~K}_{2} \mathrm{O}$ & 1.3 \\
pH & 6.8 & $\mathrm{Na}_{2} \mathrm{O}$ & 0.76 \\
$\mathrm{CaO}$ & 21.89 & $\mathrm{TiO}_{2}$ & 0.45 \\
$\mathrm{SiO}_{2}$ & 46.53 & $\mathrm{P}_{2} \mathrm{O}_{5}$ & 0.1 \\
\hline
\end{tabular}

minerals of soil were $\mathrm{Cao}$ and $\mathrm{SiO}_{2}$, and $19.1 \%$ of the soil was L.O.I. It should be mentioned that the presence of various salts and ions in the soil could act as electrolytes and then increase the flow of electro-osmosis in the processing fluid. These conditions are a desire for degradation of the pollutants using the EKR process, and no additional electrolytes were essential. The presence of various ions could affect the migration between cathode and anode electrodes. These results are found with the degradation of phenanthrene from polluted soils using the EKR process (Alcántara et al. 2012).

\section{CCD modeling and statistical analysis}

The CCD experiment design for PHE removal is shown in Table 3. According to the results obtained, the highest and lowest amounts of PHE removed were 97 and 20\%, respectively. The best model to fit the experimental data with independent variables was the quadratic polynomial. The relation between the independent and dependent (response) variables are presented as coded units in Eq. (10):

$$
\begin{aligned}
\text { Removal }= & +56.41-13.74 \times A+13.81 \times B+7.13 \\
& \times C+3.59 \times D-3.65 \times A \times B-1.47 \times A \\
& \times C-0.15 \times A \times D-0.100 \times B \times C-0.52 \\
& \times B \times D+0.15 \times C \times D-2.59 \times A^{2}-1.59 \\
& \times B^{2}+2.91 \times C^{2}-1.59 \times D^{2}
\end{aligned}
$$

The ANOVA results for the quadratic model in prediction of the PHE removal efficiency by four variables are presented in Table 4. The ANOVA is applied to assign the significance of the model. The $p$ values $<0.05$ showing the model terms are significant (Cruz-González et al. 2012). In this study, the variables $\mathrm{A}, \mathrm{B}, \mathrm{C}, \mathrm{AB}, \mathrm{AC}$, and $\mathrm{C}^{2}$ with a $p$ value $<0.05$ were significant model terms. This implies that the suggested model was correctly specified. As shown in Table 4, the parameter of the lack of fit was not significant. In other words, the model is 
Table 3 Experimental design and response values at different runs for PHE removal

\begin{tabular}{|c|c|c|c|c|c|}
\hline Run & $\mathrm{pH}$ & Time $(\mathrm{h})$ & Voltage (V) & Electrolyte concentration (\%) & Removal (\%) \\
\hline 1 & 6 & 96 & 0.5 & 2.5 & 50 \\
\hline 2 & 3 & 24 & 3 & 1 & 53 \\
\hline 3 & 6 & 96 & 1.75 & 2.5 & 57 \\
\hline 4 & 6 & 96 & 1.75 & 4 & 61 \\
\hline 5 & 3 & 168 & 3 & 4 & 97 \\
\hline 6 & 9 & 96 & 1.75 & 2.5 & 41 \\
\hline 7 & 6 & 96 & 3 & 2.5 & 70 \\
\hline 8 & 9 & 24 & 3 & 4 & 38 \\
\hline 9 & 9 & 24 & 0.5 & 1 & 20 \\
\hline 10 & 9 & 24 & 0.5 & 4 & 27 \\
\hline 11 & 3 & 168 & 0.5 & 1 & 75 \\
\hline 12 & 9 & 24 & 3 & 1 & 32 \\
\hline 13 & 6 & 96 & 1.75 & 2.5 & 54 \\
\hline 14 & 3 & 24 & 0.5 & 4 & 46 \\
\hline 15 & 9 & 168 & 3 & 4 & 58 \\
\hline 16 & 6 & 96 & 1.75 & 2.5 & 56 \\
\hline 17 & 6 & 24 & 1.75 & 2.5 & 44 \\
\hline 18 & 9 & 168 & 0.5 & 1 & 42 \\
\hline 19 & 3 & 168 & 0.5 & 4 & 78 \\
\hline 20 & 6 & 168 & 1.75 & 2.5 & 67 \\
\hline 21 & 6 & 96 & 1.75 & 2.5 & 55.8 \\
\hline 22 & 9 & 168 & 0.5 & 4 & 48.6 \\
\hline 23 & 3 & 24 & 3 & 4 & 62 \\
\hline 24 & 3 & 24 & 0.5 & 1 & 37 \\
\hline 25 & 6 & 96 & 1.75 & 2.5 & 54.7 \\
\hline 26 & 3 & 168 & 3 & 1 & 90 \\
\hline 27 & 9 & 168 & 3 & 1 & 52 \\
\hline 28 & 6 & 96 & 1.75 & 1 & 50 \\
\hline 29 & 3 & 96 & 1.75 & 2.5 & 68 \\
\hline 30 & 6 & 96 & 1.75 & 2.5 & 56.9 \\
\hline
\end{tabular}

Table 4 ANOVA of the quadratic model for the removal efficiency of PHE

\begin{tabular}{lllllll}
\hline Source & Sum of squares & df & Mean square & $F$ value & $p$ value \\
\hline Model & 8317.54 & 14 & 594.11 & 143.6 & $<0.0001$ & Significant \\
A-pH & 3400.38 & 1 & 3400.38 & 821.9 & $<0.0001$ & Significant \\
B-time & 3433.44 & 1 & 3433.44 & 829.89 & $<0.0001$ & Significant \\
C-voltage & 915.92 & 1 & 915.92 & 221.39 & $<0.0001$ & Significant \\
D-electrolyte concentration & 231.84 & 1 & 231.84 & 56.04 & $<0.0001$ & significant \\
AB & 213.16 & 1 & 213.16 & 51.52 & $<0.0001$ & Significant \\
AC & 34.81 & 1 & 34.81 & 8.41 & 0.0110 & Significant \\
C & 21.97 & 1 & 21.97 & 5.31 & 0.0359 & Significant \\
Residual & 62.06 & 15 & 4.14 & & & Not significant \\
Lack of fit & 54.94 & 10 & 5.49 & 3.86 & 0.0745 \\
Pure error & 7.11 & 5 & 1.42 & & & \\
Cor total & 8379.6 & 29 & & & &
\end{tabular}


Fig. 1 Graphs of a normal plot of the residual, $\mathbf{b}$ predicted vs. actual value plot, and $\mathbf{c}$ the plot of studentized residuals vs. predicted response for PHE removal (a)

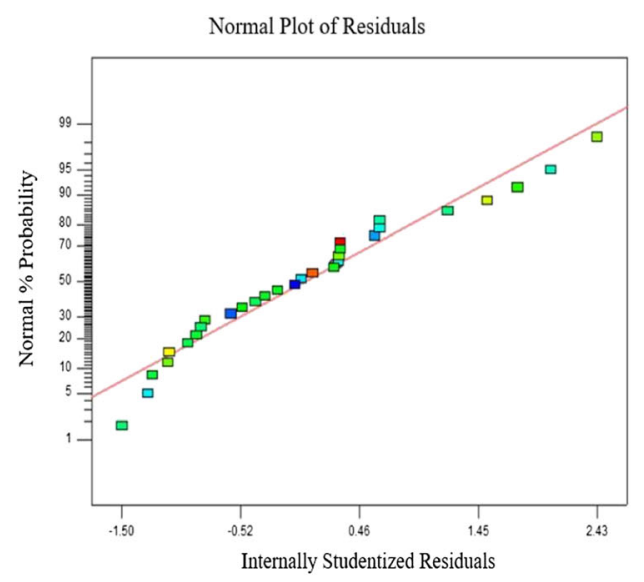

(b)

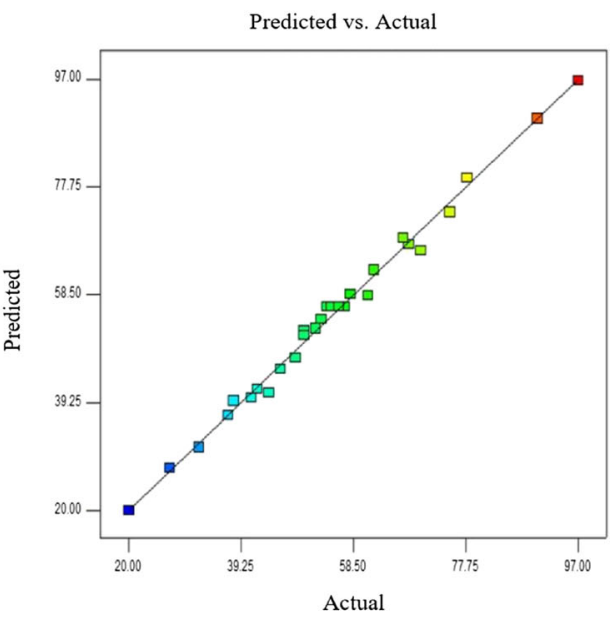

(c)



appropriate that its test of lack of fit is not significant and the $p$ value is greater than 0.05 . The model $F$ value was 143.60 ; it implies that the model is significant and could demonstrate the relationship between response and input variables. There is only a $0.01 \%$ probability that a "model $F$ value" of this large could occur due to noise (Salahi et al. 2013). Also, the values of correlation coefficient $R^{2}$, adjusted $R^{2}$, and predicted $R^{2}$ are expressed in Table 4. The results illustrated that the "Pred RSquared" of 0.9670 is in reasonable agreement with the "Adj R-Squared" of 0.9857. Therefore, it is clear that the suggested method is accurate in predicting the response. The value of the correlation coefficient $\left(R^{2}=0.992\right)$ identified that only $0.8 \%$

Fig. 2 Effect of $\mathrm{pH}$ and time on the electro-kinetic reduction of PHE (concentration of electrolyte $=2.5$, voltage $=1.75$ )

Fig. 3 Effect of $\mathrm{pH}$ and voltage on the electro-kinetic reduction of PHE (time $=96$, concentration of electrolyte $=2.5$ )
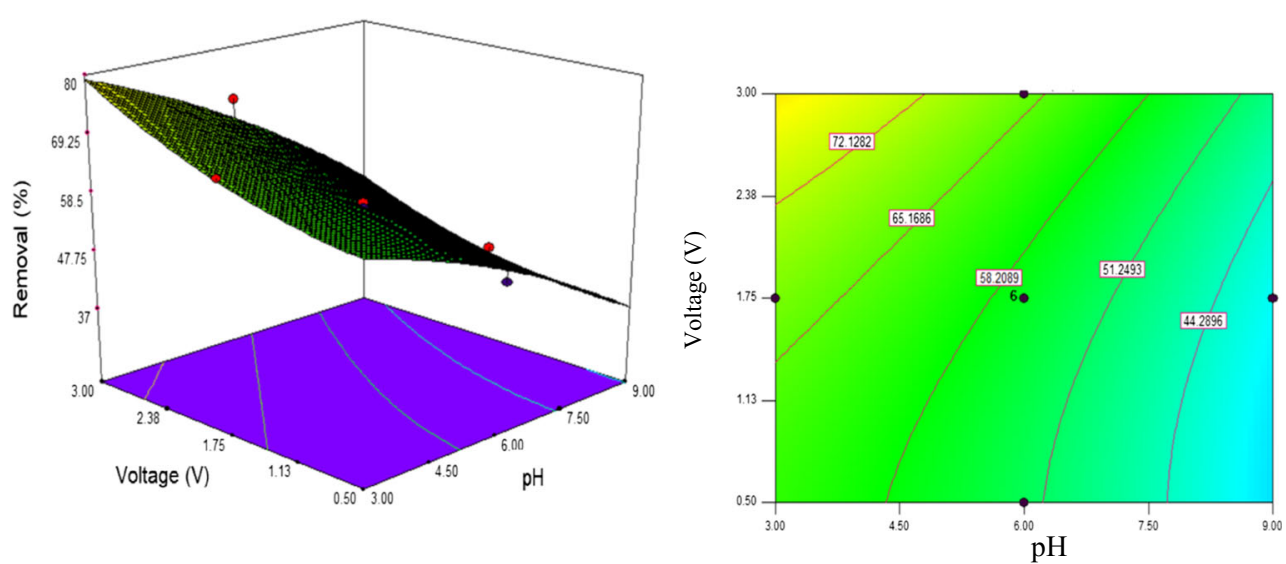

of the total variation could not be explained by the empirical model (Meriç et al. 2005). According to Eq. 13, the main factors of A, B, C, and D have the coefficients of $-13.74,+$ $13.81,+7.13$, and +3.59 , respectively. The main factor belongs to the code of B that is specified with the coefficient of + 13.81. In other words, the positive effect of a factor is shown that by increasing factor level, the response is better $(\mathrm{Ng}$ et al. 2015; Yousefi et al. 2018). To properly interpret data from graphs normal plot of the residual, predicted vs. actual value plot and outlier plot were used. As seen in Fig. 1a, the plot of residual followed a normal distribution and approximately linear. When the residuals did not follow a normal distribution, an S-shaped curve is formed, and this type of curve often resulted in the use of an incorrect model (Salahi et al. 2013; Yuliwati et al. 2012). Actual values against predicted values are represented in Fig. 1b; it is clear that the data points are near the diagonal line and the developed model is appropriate for the prediction of each response. The values of $R^{2}$ and $R^{2}$ adj were 0.99 and 0.98 , respectively; this shows that there is satisfactory agreement between actual data and predicted data.
The outlier $t$ plot for all runs is presented in Fig. 1c. The outlier t plot simply identified the magnitude of the residuals for each run to determine if any of the runs have particularly large residuals (Roychowdhury and Mitra 2017). As to be observed, all points on plots are within a threshold of between 3 and -3 , which is employed as a definition of an interval; the point outlier of this interval showed a potential error in the model or an operational error in the experimental data. As shown in Fig. 1c, there is no data outside the interval 3; this means that the model is compatible with all the data (Salahi et al. 2013; Yousefi et al. 2018).

\section{Effect of independent variables on PHE removal}

\section{Effect of $\mathrm{pH}$ and time}

To determine the interactive effect of two factors on the removal of PHE, a three-dimensional (3D) model and plot surfaces were used. Figure 2 shows the interactive effect of $\mathrm{pH}$ and time on the $\mathrm{PHE}$ removal. Effect of $\mathrm{pH}$ in the range of 3 to

Table 5 Comparison of phenanthrene removal from the soil by different methods

\begin{tabular}{|c|c|c|c|c|}
\hline Pollutant & Methods & Conditions & Removal efficiency (\%) & References \\
\hline $\begin{array}{l}\text { Phenanthrene } \\
\text { and pyrene }\end{array}$ & $\begin{array}{l}\text { By different planting patterns with rape } \\
\text { (Brassica campestris) and alfalfa } \\
\text { (Medicago sativa) }\end{array}$ & $\begin{array}{l}\text { Times }=70 \text { days, concentrations of } \\
\text { phenanthrene and pyrene: } 20.05-322.06 \\
\mathrm{mg} / \mathrm{kg} \text { and } 20.24-321.42 \mathrm{mg} / \mathrm{kg}\end{array}$ & $\begin{array}{l}43.26 \text { and } 40.38 \text { for } \\
\text { phenanthrene } 11.03 \\
\text { and } 16.29 \text { for pyrene }\end{array}$ & $\begin{array}{l}\text { Sheng-wang } \\
\text { et al. (2008) }\end{array}$ \\
\hline $\begin{array}{r}\text { Phenanthrene } \\
\text { and pyrene }\end{array}$ & $\begin{array}{l}\text { Agro-industrial waste and microbial } \\
\text { consortia }\end{array}$ & $\begin{array}{l}\text { Times }=60 \text { day concentrations of } \\
\text { phenanthrene and pyrene:50 } \mathrm{mg} / \mathrm{kg}\end{array}$ & 65 and 80 & $\begin{array}{l}\text { Cavalcanti et al. } \\
\text { (2019) }\end{array}$ \\
\hline $\begin{array}{l}\text { Phenanthrene } \\
\text { and pyrene }\end{array}$ & Surfactant washing with photocatalysis & $\begin{array}{c}\text { times }=2 \mathrm{~h} \text {, concentrations of phenanthrene } \\
\text { and pyrene were at } 1136.47 \mathrm{mg} / \mathrm{kg} \text { and } \\
1178.14 \mathrm{mg} / \mathrm{kg}, 250-\mathrm{W} \text { UV lamps }\end{array}$ & $\begin{array}{l}76.22 \text { for phenanthrene } \\
\text { and } 72.91 \text { for pyrene }\end{array}$ & $\begin{array}{l}\text { Yang et al. } \\
\text { (2014) }\end{array}$ \\
\hline Phenanthrene & $\begin{array}{l}\text { Bacterial-Fungal co-cultures: } \\
\text { Pseudomonas cepacea - Penicillium sp. } \\
\text { Ralstonia pickettii - Penicillium sp. } \\
\text { Pseudomonas aeruginose - Penicillium sp. }\end{array}$ & $\begin{array}{l}\text { Times }=18 \text { days, concentrations of } \\
\text { phenanthrene } 200 \mathrm{mg} / \mathrm{kg}\end{array}$ & $\begin{array}{l}72.84 \\
73.61 \\
\text { and } 69.47\end{array}$ & $\begin{array}{l}\text { Chávez-Gómez } \\
\text { et al. (2003) }\end{array}$ \\
\hline Phenanthrene & Electro-kinetic process & $\begin{array}{l}\mathrm{pH}: 3 \text {, time }=168 \mathrm{~h} \text {, voltage of } 3 \mathrm{~V} \text {, electrolyte } \\
\text { concentration of } 4 \mathrm{mg} / \mathrm{L} \\
\text { Concentrations of phenanthrene } 200 \mathrm{mg} / \mathrm{kg}\end{array}$ & 97 & This study \\
\hline
\end{tabular}






Fig. 4 First-order kinetic model for degradation of PHE using electrokinetic reduction (concentration of electrolyte $=2.5$, voltage $=1.75$ )

9 and the effect of time in the range 24 to $168 \mathrm{~h}$ on the removal PHE by EK remediation process were investigated. As seen in this figure, by increasing the $\mathrm{pH}$ from 3 to 9 , the removal efficiency of PHE declined and reached 20\%. Due to the oxidation/reduction of water, $\mathrm{H}^{+}$and $\mathrm{OH}^{-}$ions are produced in the anode/cathode electrode that creates an acidic/basic condition in the soil; $\mathrm{pH}$ changes of soil are affected on the migration of pollutants, and the electro-osmotic flow is determinative in the removal of non-charged organic pollutants; in other words, the electrolysis reaction at the anode electrode leads to the production of a higher concentration of $\mathrm{H}^{+}$ions, which causes decrease of the electro-osmotic flow towards the cathode, in the results $\mathrm{pH}$ of soil near the anode zone decline. The higher efficiency in acidic $\mathrm{pH}$ could be because of the hydroxyl radicals $(\mathrm{HO} \bullet)$, mostly produced in acidic $\mathrm{pH}$. Hydroxyl radicals are strong oxidant agents that react with organic pollutants and cause their destruction. In the graphite electrode according to Eq. (5), hydrogen peroxide $\left(\mathrm{H}_{2} \mathrm{O}_{2}\right)$ can be generated as a result of redox reactions, and in the presence of iron electrode as anode, a Fenton-like reaction occurs, that is, an advanced oxidation process, which leads to the

Table 6 GC-MS analysis of the contaminated soil to PHE before and after the EKR process

\begin{tabular}{llll}
\hline Structure & $\mathrm{RT}(\mathrm{min})$ & Chemical formula & $\mathrm{m} / \mathrm{z}(\mathrm{g} / \mathrm{mol})$ \\
\hline Phenanthrene & 9.82 & $\mathrm{C}_{14} \mathrm{H}_{10}$ & 178.23 \\
Phthalic acid & 6.84 & $\mathrm{C}_{8} \mathrm{H}_{6} \mathrm{O} 4$ & 166.13 \\
9.10-Phenanthraquinone & 8.79 & $\mathrm{C}_{14} \mathrm{H}_{8} \mathrm{O}_{2}$ & 208.216 \\
Dictoyl phthalate & 9.02 & $\mathrm{C}_{24} \mathrm{H}_{38} \mathrm{O}_{4}$ & 390.6 \\
1,2-Propaedione,1-phenyl & 12.1 & $\mathrm{C}_{9} \mathrm{H}_{8} \mathrm{O}_{2}$ & 148.16 \\
Octadecanoic acid & 14.22 & $\mathrm{C}_{18} \mathrm{H}_{36} \mathrm{O}_{2}$ & 284.5 \\
Hexadecane & 21.04 & $\mathrm{C}_{16} \mathrm{H}_{34}$ & 226.44 \\
\hline
\end{tabular}

production of hydroxyl radicals $(\mathrm{HO} \bullet)$. On the other hand, by increasing $\mathrm{pH}$, hydrogen peroxide is destroyed and no hydroxyl radical is formed (Oonnittan et al. 2009; Pourfadakari et al. 2019; Reddy and Saichek 2004).

\section{Effect of $\mathrm{pH}$ and voltage}

The interactive effect of $\mathrm{pH}$ and applied potential (voltage) on the removal of PHE is presented as 3D model and plot surfaces (Fig. 3). The effect of $\mathrm{pH}$ in the range of 3 to 9 and the effect of applied potential in the range 0.5 to $3 \mathrm{~V}$ on the removal PHE by EK remediation process were determined. It was found that the removal efficiency of PHE increased with decreasing $\mathrm{pH}$. The high removal rates of PHE at highly applied potential (voltage) were obtained for the electro-kinetic remediation process. This enhancement can be explained by the formation of reactive species of free radicals for PHE removal. The highly applied potential could enhance the removal efficiency and shorten remediation time due to the creation of high free radicals and gas in anode and cathode. The electrode passivation and migration of generated gas into the soil close to the cathode and anode could be affected by electrode potential (Asadollahfardi et al. 2018; Streche et al. 2018). The removal efficiency of phenanthrene in the other study has been summarized in Table 5 .

\section{Kinetic study}

The chemical reaction rate could be determined through a kinetic study. The concentration of one reactant is the main concept of the first-order model, while second-order kinetic rates could be determined by the concentration(s) of two reactants of first-order or one reactant of second-order. The firstand second-order kinetic models can be calculated through Eqs. (11) and (12), respectively (Yousefi et al. 2019).

$\ln \frac{C_{0}}{C_{\mathrm{t}}}=k_{1} t$

$\frac{1}{C_{\mathrm{t}}}-\frac{1}{C_{0}}=k_{2} t$

where $C_{0}(\mathrm{mg} / \mathrm{L})$ is the initial concentration and $C_{\mathrm{t}}(\mathrm{mg} / \mathrm{L})$ is the residual concentration after experiments. Besides, $t$ (min) is the reaction time and $k_{1}$ and $k_{2}$ are the constant rates of firstand second-order models, respectively (Huang et al. 2012; Malakootian et al. 2015). In this study, the kinetic rates of the removal PHE by the EK remediation process best fitted with the first-order kinetic model $\left(R^{2}: 0.926\right)$. The first-order kinetic model for the degradation of PHE using electro-kinetic reduction is shown in Fig. 4. 
Fig. 5 GC-MS analysis images of the PHE-contaminated soil before and after the EKR process

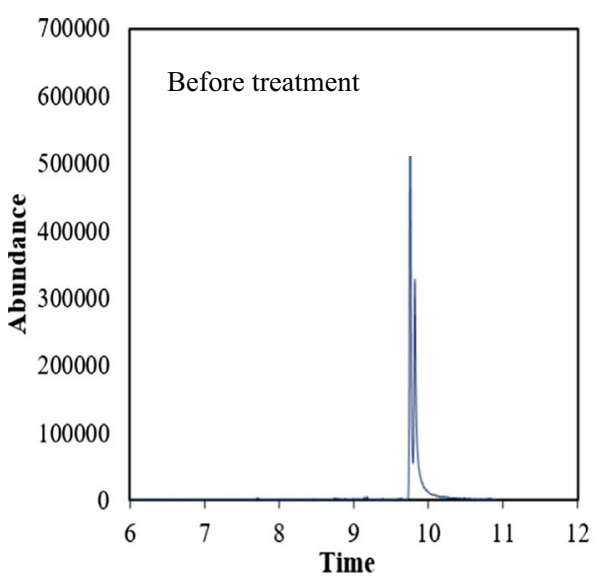



\section{Mineralization and intermediates of PHE degradation}

The intermediates of degradation of soil contaminated through PHE using the electro-kinetic process are shown in Table 6. In addition, the GC-MS analysis and graphs for intermediates degradation are shown in Fig. 5. Based on the results, degradation of the PHE was carried out during the process and simpler and aliphatic hydrocarbon was generated. The intermediates of 9.10-phenanthraquinone and dictoyl phthalate are the main by-products of this process (Manan et al. 2019).

Based on the results of the GC-MS analysis and byproducts obtained from this study, the pathway of PHE degradation using the electro-kinetic process is suggested and presented in Fig. 6. All intermediates were selected according to the GC-MS analysis. As seen in Fig. 6, while the PHE decomposition had been continued, more simple and aliphatic compounds were generated (Cameselle et al. 2013). Also, it can be predicted that by increasing time, PHE is significantly degraded and converted to mineral compounds. In addition, the independent variables, which are explained in "Lab-scale experiments," can influence the degradation rate and final product. Long-time and low-difference potential and $\mathrm{pH}$ can play more role in the removal efficiency and products generated during the EKR process. Reaction which occurred at optimal states could cause a good condition for completing the process and generating final products which mineralized to $\mathrm{CO}_{2}$ and water.

\section{Energy consumption}

The cost of energy could play as a limiting factor for the application of the full scale of electro-kinetic reduction. Environmental factors like electrical conductivity, humidity content, and $\mathrm{pH}$ could affect energy consumption. Among
Fig. 6 Proposed degradation pathway for oxidative degradation of phenanthrene by EKR process
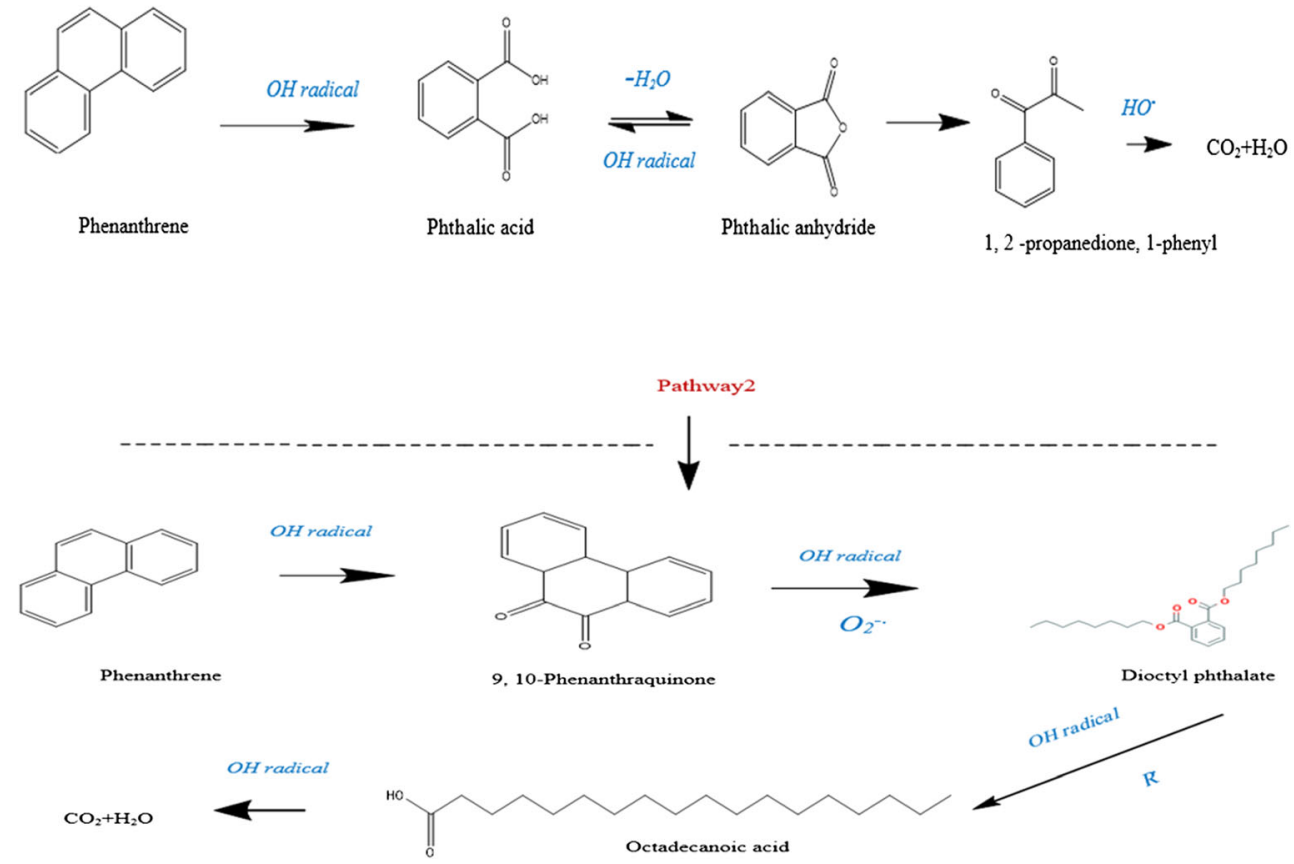
Fig. 7 Optimization of energy consumption for degradation of PHE using electro-kinetic reduction

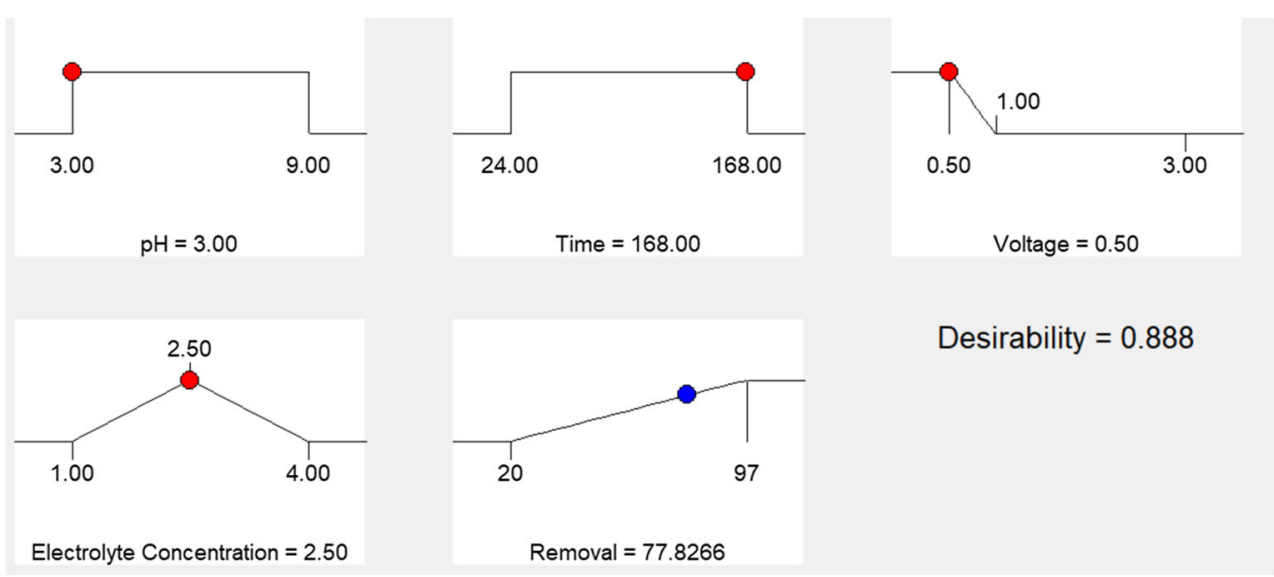

these factors, $\mathrm{pH}$ and electrical conductivity could play a critical role in the electro-kinetic remediation process. As the electrical conductivity is high, the current density increases. Thus, the lower applied potential is required to create a good condition for the electrode passivation and decreasing energy consumption (Manan et al. 2019; Mohamadi et al. 2019). These results are consistent with the study which was performed by Streche et al. (Streche et al. 2018). On the other hand, the efficiency of the process also is very important to select the degradation of pollutants. Therefore, the optimization of the EKR process was carried out for the degradation of PHE (Fig. 7). Based on the results, acidic $\mathrm{pH}, 168 \mathrm{~h}$ of time, voltage of $0.5 \mathrm{~V}$, and electrolyte concentration of $2.5 \mathrm{mg} / \mathrm{L}$ were obtained to achieve the degradation of $77.8 \%$. In the optimum experimental conditions and initial concentration PHE of $200 \mathrm{mg} / \mathrm{kg}$, the energy consumption was calculated according to Eq. (13) (Abtahi et al. 2018):

$P={ }^{V I t} /_{M .1000}$

where $E$ is the energy consumption $(\mathrm{kWh} / \mathrm{kg}), V$ is a voltage between the electrodes (V), $t$ is the electrolysis time (h), $I$ is the applied current intensity (A), and $M$ is the soil mass. According to the obtained results, the energy consumption was calculated to be $0.37 \mathrm{kWh} / \mathrm{kg}$ for soil remediation. This finding is in accordance with study Streche et al. (2018).

\section{Optimization of EKR process}

The best anticipation and optimization of factors used in the study could take place using response surface methodology and design-expert software. The quadratic model could appropriately predict the optimum value of factors (Jorfi et al. 2017a; Manan et al. 2019). The results of the optimization are shown in Fig. 8. It was found that in values of $\mathrm{pH} 3$, time of $168 \mathrm{~h}$, voltage of $3 \mathrm{~V}$, and electrolyte concentration of 4 $\mathrm{mg} / \mathrm{L}$, the removal efficiency of $96.6 \%$ for PHE was obtained.

\section{Conclusion}

The optimization of experiments and processes to increase the removal efficiency of hydrocarbon compounds is an important issue. In the removal of phenanthrene as a hydrophobic organic carbon using the EKR process, the response surface methodology was used for optimizing the effective factors. The best model to fit the experimental data with independent variables was the quadratic polynomial.




Fig. 8 Optimization of degradation of PHE using electrokinetic reduction 
In this study, most parameters had a significant effect on PHE removal ( $p$ value $<0.05$ ). This means that the proposed model was correctly fitted. The factor of the lack of fit was not significant. In other words, the $p$ value was greater than 0.05 , which means that the model obtained, based on the experimental data, could appropriately predict the results. The $F$ value of 143.60 implies the model was significant. It means that the model could demonstrate the relationship between response and input variables. Also, the values of $R^{2}$ and $R^{2}$ adj were 0.99 and 0.98 , respectively; this shows that there is a satisfactory agreement between actual data and predicted data (the difference between $R^{2}$-adjusted and predicted- $R^{2}$ was less than 0.2 ). The results of optimization showed that at acidic $\mathrm{pH}$, time of $168 \mathrm{~h}$, voltage of $0.5 \mathrm{~V}$, and electrolyte concentration of $2.5 \mathrm{mg} / \mathrm{L}$, the removal rates of PHE was $77.8 \%$. Also, based on the results, at voltage of $0.5 \mathrm{~V}, \mathrm{pH}$ of 9 , and electrolyte concentration of $1 \mathrm{mg} / \mathrm{L}$, the removal efficiency of PHE after $24 \mathrm{~h}$ of time declined and reached $20 \%$. However, the high removal rates of PHE at highly applied potential (voltage) were obtained.

Funding information The financial supports of the present work were provided by Shahroud University of Medical Sciences, (Project number: 9901).

\section{Compliance with ethical standards}

Conflict of interest The authors declare that they have no conflict of interest.

\section{References}

Abtahi M, Jorfi S, Mehrabi N, Saeedi R, Darvishi Cheshmeh Soltani R (2018) A novel combination of surfactant addition and persulfateassisted electrokinetic oxidation for remediation of pyrenecontaminated soil. Chem Biochem Eng Q 32:55-69. https://doi. org/10.15255/CABEQ.2017.1204

Alcántara MT, Gómez J, Pazos M, Sanromán MA (2009) PAHs soil decontamination in two steps: desorption and electrochemical treatment. J Hazard Mater 166:462-468. https://doi.org/10.1016/j. jhazmat.2008.11.050

Alcántara M, Gómez J, Pazos M, Sanromán MA (2012) Electrokinetic remediation of lead and phenanthrene polluted soils. Geoderma 173: 128-133. https://doi.org/10.1016/j.geoderma.2011.12.009

Amin MM, Bina B, Taheri E, Fatehizadeh A, Ghasemian M (2016) Stoichiometry evaluation of biohydrogen production from various carbohydrates. Environ Sci Pollut Res 23:20915-20921. https://doi. org/10.1007/s11356-016-7244-6

Asadollahfardi G, Rezaee M, Asadollahfardi G, Rezaee M (2018) Electrokinetic remediation of diesel-contaminated silty sand under continuous and periodic voltage application. Environ Eng Res 24: 456-462. https://doi.org/10.4491/eer.2018.301

Baneshi MM, Kalantary RR, Jafari AJ, Nasseri S, Jaafarzadeh N, Esrafili A (2014) Effect of bioaugmentation to enhance phytoremediation for removal of phenanthrene and pyrene from soil with Sorghum and Onobrychis sativa. J Environ Health Sci Eng 12:24. https://doi. org/10.1186/2052-336X-12-24
Cameselle C, Gouveia S, Akretche DE, Belhadj B (2013) Advances in electrokinetic remediation for the removal of organic contaminants in soils. Organic Pollutants-Monitoring, Risk and Treatment PP: 210-229. https://doi.org/10.5772/54334.

Cavalcanti TG, de Souza AF, Ferreira GF, Dias DSB, Severino LS, Morais JPS, de Sousa KA, Vasconcelos U (2019) Use of agroindustrial waste in the removal of phenanthrene and pyrene by microbial consortia in soil. Waste Biomass Valorization 10:205-214. https://doi.org/10.1007/s12649-017-0041-8

Chávez-Gómez B, Quintero R, Esparza-Garcia F, Mesta-Howard A, de la Serna FZD, Hernández-Rodriguez C et al (2003) Removal of phenanthrene from soil by co-cultures of bacteria and fungi pregrown on sugarcane bagasse pith. Bioresour Technol 89:177-183. https://doi. org/10.1016/S0960-8524(03)00037-3

Cruz-González K, Torres-Lopez O, García-León AM, Brillas E, Hernández-Ramírez A, Peralta-Hernández JM (2012) Optimization of electro-Fenton/BDD process for decolorization of a model azo dye wastewater by means of response surface methodology. Desalination 286:63-68. https://doi.org/10.1016/j.desal.2011.11. 005

Díez A, Iglesias O, Rosales E, Sanromán M, Pazos M (2016) Optimization of two-chamber photo electro Fenton reactor for the treatment of winery wastewater. Proc Saf Environ Prot 101:72-79. https://doi.org/10.1016/j.psep.2015.09.010

Ebrahimi A, Taheri E, Ehrampoush MH, Nasiri S, Jalali F, Soltani R, Fatehizadeh A (2013) Efficiency of constructed wetland vegetated with Cyperus alternifolius applied for municipal wastewater treatment. J Environ Public Health 2013:1-5. https://doi.org/10.1155/ 2013/815962

Huang D, Xu Q, Cheng J, Lu X, Zhang H (2012) Electrokinetic remediation and its combined technologies for removal of organic pollutants from contaminated soils. Int J Electrochem Sci 7:4528-4544. https://doi.org/10.1016/j.coelec.2018.07.005

Jahangiri K, Yousefi N, Ghadiri SK, Fekri R, Bagheri A, Talebi SS (2019) Enhancement adsorption of hexavalent chromium onto modified fly ash from aqueous solution; optimization; isotherm, kinetic and thermodynamic study. J Disper Sci Technol 40:1147-1158. https://doi.org/10.1080/01932691.2018.1496841

Javid A, Roudbari A, Yousefi N, Fard MA, Barkdoll B, Talebi SS, Nazemi S, Ghanbarian M, Ghadiri SK (2020) Modeling of chromium (VI) removal from aqueous solution using modified greengraphene: RSM-CCD approach, optimization, isotherm, and kinetic studies. J Environ Health Sci Eng 1-15. https://doi.org/10.1007/ s40201-020-00479-8.

Jorfi S, Kakavandi B, Motlagh HR, Ahmadi M, Jaafarzadeh N (2017a) A novel combination of oxidative degradation for benzotriazole removal using TiO2 loaded on FeIIFe2IIIO4@ C as an efficient activator of peroxymonosulfate. Appl Catal B Environ 219:216-230. https://doi.org/10.1016/j.apcatb.2017.07.035

Jorfi S, Pourfadakari S, Ahmadi M (2017b) Electrokinetic treatment of high saline petrochemical wastewater: evaluation and scale-up. J Environ Manag 204:221-229. https://doi.org/10.1016/j.jenvman. 2017.08.058

Kalali A, Ebadi T, Rabbani A, Moghaddam SS (2011) Response surface methodology approach to the optimization of oil hydrocarbon polluted soil remediation using enhanced soil washing. Int J Environ Sci Technol 8:389-400. https://doi.org/10.1007/BF03326226

Kumar N, Tyagi R, Tyagi V (2018) Efficiency of single and mixed dimeric surfactants micelles on solubilization of polycyclic aromatic hydrocarbons. Appl Chem Eng 2:1-6. https://doi.org/10.24294/ace. v2i1.545

Lin W, Guo C, Zhang H, Liang X, Wei Y, Lu G, Dang Z (2016) Electrokinetic-enhanced remediation of phenanthrenecontaminated soil combined with Sphingomonas sp. GY2B and biosurfactant. Appl Biochem Biotechnol 178:1325-1338. https:// doi.org/10.1007/s12010-015-1949-8 
Makkar RS, Rockne KJ (2003) Comparison of synthetic surfactants and biosurfactants in enhancing biodegradation of polycyclic aromatic hydrocarbons. Environ Toxicol Chem: An Int J 22:2280-2292. https://doi.org/10.1897/02-472

Malakootian M, Yousefi N, Fatehizadeh A, Van Ginkel SW, Ghorbani M, Rahimi S, Ahmadian M (2015) Nickel (II) removal from industrial plating effluent by Fenton process. Environ Eng Manag J 14: 837-842. https://doi.org/10.30638/eemj.2015.093

Manan TSBA, Khan T, Sivapalan S, Jusoh H, Sapari N, Sarwono A, Ramli RM, Harimurti S, Beddu S, Sadon SN (2019) Application of response surface methodology for the optimization of polycyclic aromatic hydrocarbons degradation from potable water using photoFenton oxidation process. Sci Total Environ 665:196-212. https:// doi.org/10.1016/j.scitotenv.2019.02.060

Meriç S, Selçuk H, Belgiorno V (2005) Acute toxicity removal in textile finishing wastewater by Fenton's oxidation, ozone and coagulationflocculation processes. Water Res 39:1147-1153. https://doi.org/10. 1016/j.watres.2004.12.021

Moghadam MJ, Moayedi H, Sadeghi MM, Hajiannia A (2016) A review of combinations of electrokinetic applications. Environ Geochem Health 38:1217-1227. https://doi.org/10.1007/s10653-016-9795-3

Mohamadi S, Saeedi M, Mollahosseini A (2019) Enhanced electrokinetic remediation of mixed contaminants from a high buffering soil by focusing on mobility risk. J Environ Chem Eng 7:103470. https:// doi.org/10.1016/j.jece.2019.103470

Mohan SV, Kisa T, Ohkuma T, Kanaly RA, Shimizu Y (2006) Bioremediation technologies for treatment of PAH-contaminated soil and strategies to enhance process efficiency. Rev Environ Sci Biotechnol 5:347-374. https://doi.org/10.1007/s11157-006-0004-1

Ng Y-S, Gupta BS, Hashim MA (2015) Effects of operating parameters on the performance of Washing-electro kinetic two-stage process as soil remediation method for lead removal. Sep Purif Technol 156: 403-413. https://doi.org/10.1016/j.seppur.2015.10.029

Oonnittan A, Shrestha RA, Sillanpää M (2009) Removal of hexachlorobenzene from soil by electrokinetically enhanced chemical oxidation. J Hazard Mater 162:989-993. https://doi.org/10.1016/j.desal. 2012.05.011

Plakas KV, Sklari SD, Yiankakis DA, Sideropoulos GT, Zaspalis VT, Karabelas AJ (2016) Removal of organic micropollutants from drinking water by a novel electro-Fenton filter: pilot-scale studies. Water Res 91:183-194. https://doi.org/10.1016/j.watres.2016.01. 013

Pourfadakari S, Ahmadi M , Takdastan A, Neisi AA, Ghafari S, Jorfi S (2019) biosurfactant produced by Pseudomonas aeruginosa strain $P F 2$ and electrokinetic oxidation of desorbed solution, effect of electrode modification with $\mathrm{Fe}_{3} \mathrm{O}_{4}$ nanoparticles. J Hazard Mater 120839. https://doi.org/10.1016/j.jhazmat.2019.120839

Pourfadakari S, Jorfi S, Ghafari S (2020) An efficient biosurfactant by Pseudomonas stutzeri Z12 isolated from an extreme environment for remediation of soil contaminated with hydrocarbons. Chem Biochem Eng Q 34:35-48. https://doi.org/10.15255/CABEQ.2019. 1718

Qiu Y, Xu M, Sun Z, Li H (2019) Remediation of PAH-contaminated soil by combining surfactant enhanced soil washing and iron-activated persulfate oxidation process. Int J Env Res Pub Health 16:441. https://doi.org/10.3390/ijerph16030441

Reddy KR, Saichek RE (2004) Enhanced electrokinetic removal of phenanthrene from clay soil by periodic electric potential application. J Environ Sci Health, Part A 39:1189-1212. https://doi.org/10.1081/ ESE-120030326

Roychowdhury S, Mitra D (2017) Fabrication of aromatic polyimide membrane to study the pervaporative separation of phenanthrene/ n-tetradecane mixtures (model diesel) and process optimization using response surface methodology. Chem Eng Commun 204: 64-78. https://doi.org/10.1080/00986445.2016.1235563
Saichek RE, Reddy KR (2003) Effect of pH control at the anode for the electrokinetic removal of phenanthrene from kaolin soil. Chemosphere 51:273-287. https://doi.org/10.1016/S00456535(02)00849-4

Salahi A, Noshadi I, Badrnezhad R, Kanjilal B, Mohammadi T (2013) Nano-porous membrane process for oily wastewater treatment: optimization using response surface methodology. J Environ Chem Eng 1:218-225. https://doi.org/10.1016/j.jece.2013.04.021

Shankar R, JG A, Loh A, UH Y (2019) A systematic study of the effects of solvents on phenanthrene photooxidation. Chemosphere 220: 900-909. https://doi.org/10.1016/j.chemosphere.2018.12.206

Sheng-wang P, Shi-qiang W, Xin Y, Sheng-xian C (2008) The removal and remediation of phenanthrene and pyrene in soil by mixed cropping of alfalfa and rape. Agric Sci China 7:1355-1364. https://doi.org/10.1016/S1671-2927(08)60185-6

Shin K-H, Kim K-W (2004) A biosurfactant-enhanced soil flushing for the removal of phenanthrene and diesel in sand. Environ Geochem Health 26:5-11. https://doi.org/10.1023/b:egah.0000020895.85344. 09

Streche C, Cocârță DM, Istrate I-A, Badea AA (2018) Decontamination of 504 petroleum-contaminated soils using the electrochemical technique: remediation degree and energy consumption. Sci Rep 8:3272. https://doi.org/10.1038/s41598-018-21606-4

SWE (1996): 846 test methods for evaluating solid waste, physical/ chemical methods. Anal Method 1311.

Takdastan A, Pourfadakari S, Jorfi S (2018) ultrasonically induced adsorption of nitrate from aquoeos solution using $\mathrm{Fe}_{3} \mathrm{O}_{4} @$ activated carbon nanocomposite. Desalin Water Treat 123:230-239. https:// doi.org/10.5004/dwt.2018.22761

Von Lau E, Gan S, Ng HK, Poh PE (2014) Extraction agents for the removal of polycyclic aromatic hydrocarbons (PAHs) from soil in soil washing technologies. Environ Pollut 184:640-649. https://doi. org/10.1016/j.envpol.2013.09.010

Yang XP, Xie LX, Tang J, Lin J (2014) Removal and degradation of phenanthrene and pyrene from soil by coupling surfactant washing with photocatalysis. Appl Mech Mater Trans Tech Publ 446-447: 1485-1489. https://doi.org/10.4028/www.scientific.net/AMM.446447.1485

Yousefi N, Nabizadeh R, Nasseri S, Khoobi M, Nazmara S, Mahvi AH (2018) Optimization of the synthesis and operational parameters for NOM removal with response surface methodology during nanocomposite membrane filtration. Water Sci Technol 77:1558-1569. https://doi.org/10.2166/wst.2018.037

Yousefi N, Pourfadakari S, Esmaeili S, Babaei AA (2019) Mineralization of high saline petrochemical wastewater using Sonoelectroactivated persulfate: degradation mechanisms and reaction kinetics. Microchem J 147:1075-1082. https://doi.org/10.1016/j.microc. 2019.04.020

Yuliwati E, Ismail A, Lau W, Ng B, Mataram A, Kassim M (2012) Effects of process conditions in submerged ultrafiltration for refinery wastewater treatment: optimization of operating process by response surface methodology. Desalination 287:350-361. https://doi. org/10.1016/j.desal.2011.08.051

Zdeněk K, Pavel T (2018) Removal of soil polycyclic aromatic hydrocarbons derived from biomass fly ash by plants and organic amendments. Plant Soil Environ 64:88-94. https://doi.org/10.17221/39/ 2018-PSE

Zhang W (2015) Batch washing of saturated hydrocarbons and polycyclic aromatic hydrocarbons from crude oil contaminated soils using biosurfactant. J Cent S Univ 22:895-903. https://doi.org/10.1007/ s11771-015-2599-2

Publisher's note Springer Nature remains neutral with regard to jurisdictional claims in published maps and institutional affiliations. 